\title{
Blood-based DNA methylation as biomarker for breast cancer: a systematic review
}

Qiuqiong Tang ${ }^{1,2}$, Jie Cheng ${ }^{1,2}$, Xue Cao ${ }^{1,2}$, Harald Surowy ${ }^{1,2}$ and Barbara Burwinkel ${ }^{1,2^{*}}$

\begin{abstract}
Multiple studies have investigated global DNA methylation profiles and gene-specific DNA methylation in bloodbased DNA to develop powerful screening markers for cancer. This systematic review summarizes the current evidence on methylation studies that investigated methylation level of blood-derived DNA of breast cancer (BC) patients in comparison to healthy controls by conducting a systematic literature review in PubMed and Web of Science. Essential results, such as methylation levels of BC cases and healthy controls, $p$ values, and odds ratios, were extracted from these studies by two investigators independently. Overall, 45 publications met the inclusion criteria for this review. DNA from whole blood, as well as cell-free DNA (cfDNA) from serum or plasma, was used in these studies. The most common method used for measuring global DNA methylation was the investigation of repetitive elements as surrogates and the application of array-based genome-wide methylation analysis. For measuring gene-specific methylation level, methylation-specific PCR and pyrosequencing were the most frequently used methods. Epigenome-wide blood DNA hypomethylation in BC patients were reported in several studies; however, the evidence is still not conclusive. The most frequently investigated gene in whole blood was BRCA1, which was found more frequently methylated in patients compared to controls. RASSF1A was the most widely investigated gene in cfDNA of serum or plasma, which was also found more frequently methylated in patients compared to controls. Several of the eligible studies reported the associations of global hypomethylation and increased BC risk. Studies investigated associations between gene-specific methylation and BC risk, while got heterogeneous results. But two studies reported that hypermethylation of ATM gene was associated with increased $\mathrm{BC}$ risk, which suggest the potential use of this gene for $\mathrm{BC}$ risk stratification. Overall, our review suggests the possibility of using blood-based DNA methylation marker as promising marker for BC risk stratification, as several studies found associations between certain methylation level in blood and BC risk. However, so far, the evidence is still quite limited. Optimal markers are yet to be developed and promising results needed to be validated in prospective study cohorts and tested in large screening populations.
\end{abstract}

Keywords: DNA methylation, Breast cancer, Blood-based biomarker, Systematic review

\section{Background}

Breast cancer $(\mathrm{BC})$ is the most common malignancy among women worldwide [1, 2]. The prognosis of this disease mainly depends on its early detection, which currently to a major part relies on mammography. Early detection of this disease can also be facilitated by new diagnostic biomarkers. The current Food and Drug Administration (FDA)-approved blood-based biomarkers for BC, such as CA15-3 and CA27-29, are solely

\footnotetext{
* Correspondence: B.Burwinkel@dkfz-heidelberg.de

${ }^{1}$ Molecular Biology of Breast Cancer, Department of Gynecology and

Obstetrics, Ruprecht-Karls-Universitaet Heidelberg, Heidelberg, Germany

${ }^{2}$ Division of Molecular Epidemiology (C080), German Cancer Research Center

(DKFZ), Heidelberg, Germany
}

recommended for the monitoring of disease relapse and treatment efficacy, rather than diagnosis [3, 4]. Specific gene mutation tests, such as $B R C A 1 / 2$ mutation analysis, are currently only used for screening of hereditary $\mathrm{BC}$ cases, which constitute only about $5-10 \%$ of total BC cases $[5,6]$. For women at normal risk of developing $\mathrm{BC}$, many national organizations recommend screening mammography for older women. In the USA, screening mammography is recommended every 2 years for women at age between 50 and 74 [7]. However, the present screening method is criticized for both low sensitivity [8] and disadvantages due to over-diagnosis 
$[9,10]$. Thus, alternative approaches for $\mathrm{BC}$ detection or risk stratification are clearly needed.

Both global hypomethylation and silencing of tumor suppressor genes through promoter hypermethylation can come along with tumor development, and both have been recognized as common hallmarks of many cancers [11]. Similar alterations can also be measured in bloodderived DNA, which suggests the possibility of bloodbased DNA methylation markers to serve as new screening markers or markers for risk stratification $[12,13]$. To date, a considerable number of studies on DNA methylation in cancer have used DNA obtained from blood (whole blood or white blood cells) or cell-free DNA (cfDNA) isolated from serum or plasma, with the assessment of differences in methylation levels between $\mathrm{BC}$ patients and cancer-free healthy controls, to identify methylation markers [14-22]. A substantial number of studies concluded that BC patients and healthy controls exhibit differential DNA methylation patterns in peripheral blood. However, numerous further studies have reported controversial findings, and clear evidence is still lacking whether DNA methylation changes could serve as biomarker for BC diagnosis or risk stratification.

The aim of this review is to summarize the current evidence on DNA methylation-associated biomarkers for $\mathrm{BC}$ risk evaluation or early detection, by performing a comprehensive systematic review of published DNA methylation studies in blood-derived DNA of BC patients in comparison to healthy controls. From each eligible study, we extracted essential information, such as age of study subjects, sample size, applied methylation detection methods, methylation levels of patients and healthy controls, $p$ values for methylation differences, and odds ratios (ORs), in order to gain insights into the currently accumulated evidence regarding the use of DNA methylation markers for potential future screening tests.

\section{Methods}

\section{Search strategy}

A systematic literature search was performed to identify studies assessing DNA methylation changes in blood as biomarkers for risk or early detection of BC. PubMed and ISI Web of Knowledge were searched for eligible articles until 31 January 2016. The following combination of keywords was used: [breast] (and) [cancer (or) neoplasm (or) carcinoma (or) adenoma (or) malignancy (or) adenoma] (and) [DNA methylation (or) methylated (or) hypermethylation (or) hypomethylation] (and) [risk (or) detection (or) diagnosis] (and) [serum (or) blood (or) plasma (or) white blood cell]. The literature search was limited to studies focusing on humans and published in English.

\section{Eligibility criteria}

Duplicate articles were removed upon combining the retrieved publications from the two databases. A first round of selection was conducted by reviewing the titles and abstracts. Only full-text reports of original studies were included, thus meeting abstracts, reviews, and editorials were excluded. Articles not focusing on DNA methylation changes in blood in the context of $\mathrm{BC}$ detection/diagnosis/risk prediction were excluded, including studies that analyzed (1) DNA methylation markers in tissue samples, (2) DNA methylation as prognostic markers of $\mathrm{BC}$ or predictive markers for $\mathrm{BC}$ treatment efficacy, and (3) DNA isolated from collected CTC cells.

After the first round examination, we conducted a full-text review for the remaining articles. In addition, studies that did not include healthy female controls, for example, only with benign breast disease patients, were not considered. Studies were also excluded if the information regarding methylation levels of $\mathrm{BC}$ cases and healthy controls or ORs were not reported or could not be extracted from published data, for example, studies that solely presented results by heatmaps or reported the methylation levels of a combination of specific loci/ genes. Cross-referencing was used as a possible source for identifying studies related to the present topic.

\section{Data extraction and statistical analysis}

Eligible studies were included in the data extraction procedure, which was conducted independently by two investigators $(\mathrm{Q}$. Tang and J. Cheng) with a standardized data extraction form. The following variables were extracted: first author, publication year, study design, age of study subjects, DNA source (whole blood, serum, or plasma), DNA methylation detection method, the type of measured DNA methylation (global or gene/locus specific), and essential results (methylation levels of cases and controls, ORs, $p$ values). Any disagreement was resolved by further review and discussion among the coauthors. In case methylation levels were not explicitly reported, the information was extracted from available tables and figures to the possible extent. If not presented in the articles, $p$ values for methylation differences between $\mathrm{BC}$ cases and healthy controls were calculated by Fisher's exact test. Reporting of data follows the PRISMA statements [23].

\section{Results}

\section{Literature overview}

The process of the systematic literature search is displayed in Fig. 1a. Briefly, the primary search in PubMed and Web of knowledge identified 945 articles, of which 206 were duplicate articles. After excluding non-eligible articles (see Fig. 1a and Additional file 1: Supplementary materials), 45 articles could be included in this review, 

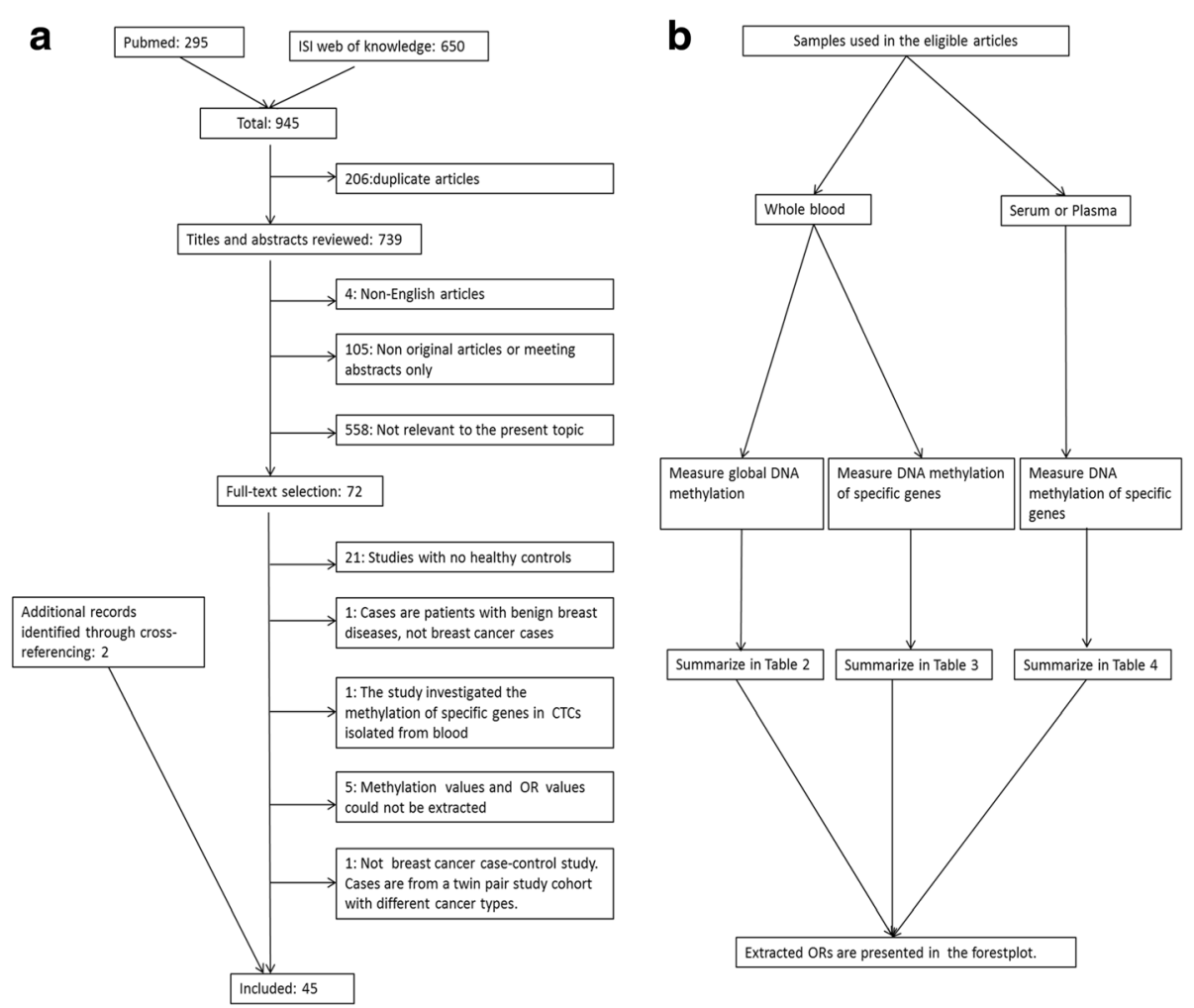

Fig. 1 a Flow diagram of the literature search process (search until 30.01.2016) and b summarize strategy of the review

including 26 articles used DNA isolated from whole blood [14-21, 24-41], two articles used DNA isolated from both whole blood and plasma [42, 43], six articles used DNA isolated from plasma [44-49], and 11 articles used DNA isolated from serum [50-60] (Table 1). For the studies that used serum or plasma as DNA source, four of them used two centrifugation steps to get serum or plasma $[42,45,47,48]$ and the rest used one centrifugation step or sample processing procedures are not available (Table 1). The included articles were published between 2004 and 2015 .

Among all eligible studies, only 11 studies investigated global DNA methylation. This was always done in DNA isolated from whole blood (Table 1). The majority of studies measured gene- or locus-specific DNA methylation levels, in DNA isolated either from whole blood or in cfDNA isolated from serum or plasma (Table 1). To get a better overview of global DNA methylation changes, as well as the differentially methylated genes between $\mathrm{BC}$ patients and healthy controls, we summarize these studies separately, as shown in Fig. 1b.

\section{Global DNA methylation in peripheral blood of BC cases and controls}

As shown in Table 2, a total of 15 studies from 11 literatures evaluated global DNA methylation levels in whole blood by different strategies. These included using mean methylation intensities of all Infinium HumanMethylation450K $(450 \mathrm{~K})$ probes ( $\beta$ value) as global DNA methylation levels, measuring the percentage of methylated DNA by luminometric methylation assay (LUMA) and the concentration of 5-methyldeoxycytosine (5$\mathrm{mdC}$ ) by liquid chromatography-mass spectrometry (LC-MS) or measuring the methylation of repetitive DNA elements (i.e., LINE-1, Alu, or Sat2) by pyrosequencing or the MethyLight assay as surrogates of global DNA methylation levels. Among them, four nested case-control studies [17-19, 38] used prospectively collected samples of $\mathrm{BC}$ cases and healthy controls, while the remaining studies used samples collected at diagnosis or shortly after diagnosis and healthy controls $[17,26,27,29,31-33,36]$. Case number of these studies was between relative large (over 100 subjects for each group), except the studies by Kitkumthorn $\mathrm{N}$ et al. (with 36 cases) [33] and Cho $\mathrm{YH}$ et al. (with 40 cases and 40 controls) [27]. Cases and controls used in these 14 studies were number- and age-matched.

As shown in Table 2, studies of van Veldhoven and Severi reported epigenome-wide hypomethylation of blood DNA in BC patients compared to controls, even that van Veldhoven et al. [18] observed lower methylation in $\mathrm{BC}$ cases in one of their study cohorts, but not in 
Table 1 Characteristics summary of the 45 eligible studies

\begin{tabular}{|c|c|c|c|c|c|c|c|c|}
\hline Number & First author & Year & Country & DNA source & Sample treatment & Measurement & $\begin{array}{l}\text { Methylation } \\
\text { levels } \\
\text { available }\end{array}$ & $\begin{array}{l}\text { Odds ratio } \\
\text { estimation } \\
\text { available }\end{array}$ \\
\hline 1 & Widschwendter M & 2008 & Germany & Blood & - & Gene-specific methylation & Yes & Yes \\
\hline 2 & Snell C & 2008 & Australia & Blood & - & Gene-specific methylation & Yes & No \\
\hline 3 & Ito $Y$ & 2008 & UK & Blood & - & Gene-specific methylation & Yes & Yes \\
\hline 4 & Flanagan. JM & 2009 & UK & Blood & - & Gene-specific methylation & Yes & Yes \\
\hline 5 & Choi JY & 2009 & USA & Blood & - & Global DNA methylation & Yes & Yes \\
\hline 6 & Cho YH & 2010 & Turkey & Blood & - & $\begin{array}{l}\text { Both global DNA methylation } \\
\text { and gene-specific methylation }\end{array}$ & Yes & No \\
\hline 7 & Hoffman AE & 2010 & Connecticut & Blood & - & Gene-specific methylation & No & Yes \\
\hline 8 & Wong EM & 2011 & Australia & Blood & - & Gene-specific methylation & Yes & Yes \\
\hline 9 & Iwamoto T & 2011 & Japan & Blood & - & Gene-specific methylation & Yes & Yes \\
\hline 10 & Brennan K & 2012 & $\begin{array}{l}\text { Australia, New } \\
\text { Zealand, UK, } \\
\text { and Europe }\end{array}$ & Blood & - & $\begin{array}{l}\text { Both global DNA methylation } \\
\text { and gene-specific methylation }\end{array}$ & Yes & Yes \\
\hline 11 & XuX & 2012 & USA & Blood & - & Global DNA methylation & Yes & Yes \\
\hline 12 & Bosviel $R$ & 2012 & France & Blood & - & Gene-specific methylation & Yes & No \\
\hline 13 & Wu HC & 2012 & USA & Blood & - & Global DNA methylation & Yes & Yes \\
\hline 14 & Delgado-Cruzata L & 2012 & USA & Blood & - & Global DNA methylation & Yes & Yes \\
\hline 15 & Kitkumthorn N & 2012 & Thailand & Blood & - & Global DNA methylation & Yes & No \\
\hline 16 & Hajikhan Mirzaei M & 2012 & Iran & Blood & - & Gene-specific methylation & Yes & No \\
\hline 17 & Askari M & 2013 & India & Blood & - & Gene-specific methylation & Yes & Yes \\
\hline 18 & Severi G & 2014 & Australia & Blood & - & Global DNA methylation & Yes & Yes \\
\hline 19 & Yang $R X$ & 2014 & Germany & Blood & - & Gene-specific methylation & Yes & Yes \\
\hline 20 & Kuchiba A & 2014 & Japan & Blood & - & Global DNA methylation & Yes & Yes \\
\hline 21 & Gupta S & 2014 & Poland & Blood & - & Gene-specific methylation & Yes & Yes \\
\hline 22 & DeRoo LA & 2014 & USA & Blood & - & Global DNA methylation & No & Yes \\
\hline 23 & van Veldhoven $\mathrm{K}$ & 2015 & Italy & Blood & - & Global DNA methylation & Yes & Yes \\
\hline 24 & Cho YH & 2015 & USA & Blood & - & Gene-specific methylation & Yes & Yes \\
\hline 25 & Yari K & 2015 & Iran & Blood & - & Gene-specific methylation & Yes & No \\
\hline 26 & Harrison $\mathrm{K}$ & 2015 & Europe & Blood & - & Gene-specific methylation & Yes & Yes \\
\hline 27 & Zmetakova I & 2013 & Slovakia & Blood and plasma & $\begin{array}{l}1000 \mathrm{~g} \text { for } 10 \\
\mathrm{~min}+1000 \mathrm{~g} \text { for } \\
10 \mathrm{~min}\end{array}$ & Gene-specific methylation & Yes & No \\
\hline 28 & Enders KN & 2014 & China & Blood and plasma & na & Gene-specific methylation & Yes & No \\
\hline 29 & Hoque MO & 2006 & Senegal & Plasma & $\begin{array}{l}2200 \mathrm{rpm} \text { for } \\
10-15 \mathrm{~min}\end{array}$ & Gene-specific methylation & Yes & No \\
\hline 30 & Papadopoulou E & 2006 & Greece & Plasma & $\begin{array}{l}2000 \text { rpm for } 10 \\
\text { min }+2000 \text { rpm } \\
\text { for } 10 \text { min }\end{array}$ & Gene-specific methylation & Yes & No \\
\hline 31 & Yazici H & 2009 & USA & Plasma & na & Gene-specific methylation & Yes & No \\
\hline 32 & Radpour R & 2011 & Switzerland & Plasma & $\begin{array}{l}16,006 \mathrm{~g} \text { for } 10 \\
\mathrm{~min}+\text { full speed } \\
10 \mathrm{~min}\end{array}$ & Gene-specific methylation & Yes & No \\
\hline 33 & Enders KO Ng & 2011 & China & Plasma & $\begin{array}{l}1600 \mathrm{~g} \text { for } 10 \\
\min +16,000 \mathrm{~g} \\
\text { for } 10 \mathrm{~min}\end{array}$ & Gene-specific methylation & Yes & No \\
\hline 34 & Chimonidou M & 2013 & Greece & Plasma & $2000 \mathrm{~g}$ for $10 \mathrm{~min}$ & Gene-specific methylation & Yes & No \\
\hline 35 & Dulaimi E & 2004 & Pennsylvania & Serum & na & Gene-specific methylation & Yes & No \\
\hline
\end{tabular}


Table 1 Characteristics summary of the 45 eligible studies (Continued)

\begin{tabular}{|c|c|c|c|c|c|c|c|c|}
\hline 36 & Martinez-Galan J & 2008 & Spain & Serum & $2000 \mathrm{~g}$ for $10 \mathrm{~min}$ & Gene-specific methylation & Yes & No \\
\hline 37 & Van der Auwera I & 2009 & Belgium & Serum & $2000 \mathrm{~g}$ for $10 \mathrm{~min}$ & Gene-specific methylation & Yes & No \\
\hline 38 & Chen Z & 2009 & China & Serum & $1000 \mathrm{~g}$ for $10 \mathrm{~min}$ & Gene-specific methylation & Yes & No \\
\hline 39 & Zurita M & 2010 & Spain & Serum & $2000 \mathrm{~g}$ for $10 \mathrm{~min}$ & Gene-specific methylation & Yes & No \\
\hline 40 & Ahmed IA & 2010 & Germany & Serum & $2000 \mathrm{~g}$ for $10 \mathrm{~min}$ & Gene-specific methylation & Yes & No \\
\hline 41 & Brooks JD & 2010 & USA & Serum & na & Gene-specific methylation & Yes & No \\
\hline 42 & Kim JH & 2010 & Korea & Serum & na & Gene-specific methylation & Yes & No \\
\hline 43 & Kloten V & 2013 & Germany & Serum & $2000 \mathrm{~g}$ for $10 \mathrm{~min}$ & Gene-specific methylation & Yes & No \\
\hline 44 & Swellam M & 2015 & Egypt & Serum & $1600 \mathrm{~g}$ for $15 \mathrm{~min}$ & Gene-specific methylation & Yes & No \\
\hline 45 & Liu LM & 2015 & China & Serum & na & Gene-specific methylation & Yes & No \\
\hline
\end{tabular}

na not available

another two study cohorts. Three studies [29, 32, 36] measured the global methylation content by LUMA assay but obtained heterogeneous results. Specifically, Kuchiba et al. [36] observed an increased global blood DNA methylation in BC patients, while Xu et al. [29] reported a decrease and Delgado-Cruzata et al. [32] found no significant methylation differences between $\mathrm{BC}$ cases and controls. Choi JY et al. [26] observed significant lower level of 5-mdC in patients compared to controls. Interestingly, nine studies from seven articles $[17,26,27,29,31,33,38]$ evaluated the methylation level of LINE-1 repeats with different detection methods, but almost all of them reported that there were no significant difference in LINE-1 methylation between BC cases and controls (Table 2). Studies investigating Sat2 and Alu repetitive elements also revealed inconsistent results (Table 2). Delgado-Cruzata L et al. [32] observed significant higher $[3 \mathrm{H}]$-methyl acceptance (lower DNA methylation) in patients than in controls.

Overall, the evidence of global DNA hypo- or hypermethylation in blood DNA of BC cases is so far limited and not conclusive. As shown in Table 2, less than half of these studies reported significant global hypomethylation in blood DNA of BC patients (Table 2) and the overall methylation difference between $\mathrm{BC}$ cases and controls are relative small (effect size varied from 0.013 to 0.25 ). This could be due to the complicated epigenetic background of DNA isolated from whole blood as well as the still high variability of quantitative DNA methylation detection methods. In addition, the eligibility of LINE-1 as surrogate for global DNA methylation level might be limited, as nine studies observed no significant difference of LINE-1 methylation between cases and controls.

Some studies also investigated the associations between blood DNA methylation levels and BC risk by quantile analysis, comparing the risk of women in the highest quantile and that of women in the lowest quantile (Fig. 2a) or vice versa (Fig. 2b). As shown in Fig. 2a,
Delgado-Cruzata and coauthors concluded that there was no significant association between global DNA methylation levels detected by LUMA assay and [3H]methyl acceptance assay and $\mathrm{BC}$ risk [32]. Wu $\mathrm{HC}$ et al. [31] and DeRoo LA et al. [38] evaluated possible associations between the methylation level of repetitive elements (LINE-1, Alu, or Sat2) of blood DNA and BC risk, but also with inconsistent results. Choi et al. used the amounts of 5-mdC as surrogates for global DNA methylation in blood and reported that women representing the lowest 5 - $\mathrm{mdC}$ quantile had a higher risk of BC (2.81, 95\% CI 1.65-4.94), compared with women of the highest quantile [26]. As shown in Fig. 2b, Xu et al. [29] and Kuchiba et al. [36] revealed a positive association between LUMA methylation level and BC risk. Three large prospective studies were reported in two articles. Here, the global DNA methylation was investigated by $450 \mathrm{~K}$ methylation arrays. Mean $\beta$ values across the whole genome were calculated and used as global DNA methylation level $[18,19]$. For women in the highest quantile compared to women in the lowest methylation quantile, the ORs $(95 \% \mathrm{CI})$ were $0.34(0.18-0.66)$ (EPIC cohort) and 0.99 (0.56-1.76) (NOWAC cohort) in the study of van Veldhoven et al. [18], and the ORs were $0.42(0.20-0.90)$ in the study of Severi and coauthors [19]. This suggests that hypomethylation in whole blood might be associated with an increased risk of $\mathrm{BC}$, even the abovementioned results are inconclusive.

Overall, the association between global DNA methylation and BC risk is still unclear, as both positive association and negative association were reported.

\section{Gene-specific methylation in whole blood DNA of BC cases and controls}

Table 3 and Additional file 1: Table S1 list all the studies that examined the methylation levels of specific gene loci in whole blood DNA of BC cases and healthy controls. All of these studies were case-control studies. The number of cases varied from only seven to 1021 . The most 
Table 2 Global DNA methylation in peripheral blood of breast cancer cases and healthy controls

\begin{tabular}{|c|c|c|c|c|c|c|c|c|c|}
\hline Measurements & Author, year [ref] & Study design & Assay (value) & $\begin{array}{l}\text { Case } \\
\text { no./control no. }\end{array}$ & $\begin{array}{l}\text { Case age/control } \\
\text { age }(y)^{\mathrm{a}}\end{array}$ & Meth (case) & Meth (control) & $p$ value & Main findings \\
\hline \multirow[t]{4}{*}{$\beta$ value } & \multirow[t]{3}{*}{$\begin{array}{l}\text { van Veldhoven K, } \\
2015 \text { [18] }\end{array}$} & \multirow[t]{3}{*}{ Nested case-control } & $\begin{array}{l}450 \mathrm{~K} \text { (EPIC cohort) } \\
\text { (mean + SD) }\end{array}$ & $162 / 162$ & $54.4 / 54.2$ & $53.00 \pm 0.39$ & $53.18 \pm 0.35$ & $1.82 \mathrm{E}-05$ & \multirow{3}{*}{$\begin{array}{l}\text { Epigenome-wide } \\
\text { hypomethylation } \\
\text { of DNA in samples } \\
\text { from EPIC cohort. }\end{array}$} \\
\hline & & & $\begin{array}{l}450 \text { K (NOWAC } \\
\text { cohort) (mean + SD) }\end{array}$ & $168 / 168$ & $55.4 / 55.4$ & $54.02 \pm 0.45$ & $54.02 \pm 0.41$ & 0.79 & \\
\hline & & & WBGS (BGS cohort) (mean) & $548 / 548$ & $52 / 52$ & 48.12 & 48.3 & na & \\
\hline & Severi G, 2014 [19] & Nested case-control & $450 \mathrm{~K}($ mean + SD) & $420 / 420$ & $64 / 64$ & $51.86 \pm 1.00$ & $51.95 \pm 1.01$ & 0.006 & $\begin{array}{l}\text { Epigenome-wide } \\
\text { hypomethylation } \\
\text { of DNA in BC patients. }\end{array}$ \\
\hline \multirow[t]{3}{*}{ LUMA } & Kuchiba A, 2014 [36] & Case-control & LUMA (\% DNA meth) & $384 / 384$ & $54.1 / 53.9$ & $68.9 \pm 3.5$ & $70.2 \pm 3.4$ & $<0.01$ & $\begin{array}{l}\text { Global genomic } \\
\text { hypomethylation } \\
\text { in BC patients. }\end{array}$ \\
\hline & Xu X, 2012 [29] & Case-control & LUMA (\%) & $1055 / 1101$ & na/na & $57.3 \pm 15.7$ & $52.4 \pm 16.7$ & $<0.0001$ & $\begin{array}{l}\text { Global promoter } \\
\text { hypermethylation } \\
\text { in patients. }\end{array}$ \\
\hline & $\begin{array}{l}\text { Delgado-Cruzata } \\
\text { L, } 2012 \text { [32] }\end{array}$ & Case-control & LUMA (\%) & $263 / 321$ & $49.5 / 48.0$ & $67.1 \pm 7.6$ & $67.5 \pm 7.3$ & $>0.05$ & $\begin{array}{l}\text { LUMA DNA methylation } \\
\text { levels were similar } \\
\text { between cases and } \\
\text { controls. }\end{array}$ \\
\hline \multirow[t]{2}{*}{$5-m d C$} & Choi JY, 2009 [26] & Case-control & $\begin{array}{l}\text { LC-MS (test set) } \\
\text { (mean) }\end{array}$ & 19/18 & $35-75 / 35-75$ & 3.98 & 4.33 & 0.001 & $\begin{array}{l}\text { Hypomethylation of } \\
5 \text {-mdC in } B C \text { patients. }\end{array}$ \\
\hline & & & $\begin{array}{l}\text { LC-MS (validation } \\
\text { set) (mean) }\end{array}$ & $176 / 173$ & $35-75 / 35-75$ & $4.18 \pm 0.34$ & $4.38 \pm 0.36$ & $<0.001$ & \\
\hline \multirow[t]{10}{*}{ LINE-1 } & $\begin{array}{l}\text { Kitkumthorn N, } \\
2012 \text { [33] }\end{array}$ & Case-control & COBRA (\%) & $36 / 144$ & $50.28 / 48.67$ & 40 & 42 & $>0.05$ & $\begin{array}{l}\text { No significant differences } \\
\text { in LINE-1 methylation } \\
\text { between BC cases and } \\
\text { healthy controls. }\end{array}$ \\
\hline & Xu X, 2012 [29] & Case-control & $\begin{array}{l}\text { Pyrosequencing } \\
\text { (mean) }\end{array}$ & $1064 / 1100$ & na/na & 78.8 & 78.8 & 0.94 & As above. \\
\hline & $\begin{array}{l}\text { Brennan K, } 2012 \\
\text { [17] }\end{array}$ & & $\begin{array}{l}\text { Pyrosequencing } \\
\text { (mean } \\
\text { and IQR) }\end{array}$ & & & & & & As above. \\
\hline & & Case-control & BGS cohort & $241 / 242$ & $54 / 54$ & $79.0(78.1-79.9)$ & $79.0(77.9-80.1)$ & 0.96 & \\
\hline & & Case-control & EPIC cohort & $232 / 263$ & $52 / 52$ & $75.2(73.9-76.3)$ & 75.1 (73.9-76.3) & 0.89 & \\
\hline & & Nested case-control & KConFab cohort & $153 / 218$ & $50 / 60$ & $76.6(75.2-77.6)$ & $76.0(74.3-78.0)$ & 0.2 & \\
\hline & Wu HC, 2012 [31] & Case-control & MethyLight (\%) & $265 / 333$ & $49.5 / 48.0$ & $107.4 \pm 63.6$ & $108.5 \pm 59.1$ & $>0.05$ & As above. \\
\hline & & & $\begin{array}{l}\text { Pyrosequencing } \\
\text { (mean) }\end{array}$ & $279 / 340$ & $49.5 / 48.0$ & $74.5 \pm 3.0$ & $74.5 \pm 2.6$ & $>0.05$ & \\
\hline & Cho YH, 2010 [27] & Case-control & MethyLight (\%) & $40 / 40$ & $50.8 / 48.3$ & 70 & 78 & $>0.05$ & As above. \\
\hline & Choi JY, 2009 [26] & Case-control & & $19 / 18$ & $35-75 / 35-75$ & 74.7 & 73.9 & 0.176 & As above. \\
\hline
\end{tabular}


Table 2 Global DNA methylation in peripheral blood of breast cancer cases and healthy controls (Continued)

\begin{tabular}{|c|c|c|c|c|c|c|c|c|c|}
\hline \multirow[t]{2}{*}{ Alu } & Wu HC, 2012 [31] & Case-control & MethyLight (\%) & $266 / 334$ & $49.5 / 48.0$ & $95.5 \pm 36.6$ & $98.7 \pm 51.5$ & $>0.05$ & $\begin{array}{l}\text { No significant differences } \\
\text { in Alu methylation } \\
\text { between } B C \text { cases and } \\
\text { healthy controls. }\end{array}$ \\
\hline & Cho YH, 2010 [27] & Case-control & MethyLight (\%) & $40 / 40$ & $50.8 / 48.3$ & 58 & 61 & $>0.05$ & As above. \\
\hline [3H]-methyl & $\begin{array}{l}\text { Delgado-Cruzata } \\
\text { L, } 2012 \text { [32] }\end{array}$ & Case-control & $\begin{array}{l}{[3 \mathrm{H}]-\text { Methyl }} \\
\text { acceptance assay }\end{array}$ & $233 / 295$ & $49.6 / 48.2$ & $97,111 \pm 76,348$ & $88,030 \pm 70,841$ & $<0.05$ & $\begin{array}{l}\text { Global genomic } \\
\text { hypomethylation } \\
\text { in } \mathrm{BC} \text { patients (more } \\
{[3 \mathrm{H}] \text {-methyl acceptance). }}\end{array}$ \\
\hline
\end{tabular}

\section{Pyrosequencing \\ (mean)}

Sat2

Deroo LA, $2014 \quad$ Nested case-control Pyrosequencing

$[38]^{\mathrm{b}}$

Wu HC, 2012 [31] Case-control MethyLight (\%)

$43.5 \pm 32.9$

$>0.05$

significant differences

in Sat2 methylation

between $\mathrm{BC}$ cases and

healthy controls.

$\begin{array}{lllll}\text { Cho YH, } 2010[27] \quad \text { Case-control } & \text { MethyLight (\%) } & 40 / 40 & 50.8 / 48.3 & 125\end{array}$

[3H]-methyl acceptance).

The numbers in italic are extracted from boxplot or scatter plots

450K Infinium HumanMethylation 450K Beadchips, WGBS whole genome bisulfite sequencing, LUMA luminometric methylation assay, COBRA combined bisulfite restriction analysis, 5-mdC 5-methyldeoxycytosine, na

not available

${ }^{a}$ Age indicates mean age or range

${ }^{\mathrm{b}}$ The mean DNA methylation level of $\mathrm{BC}$ cases and controls is not available; the study only reported the results of the quartile analysis 


\section{a \\ Global DNA methylation and $\mathrm{BC}$ risk ( highest methylation quantile as reference)}

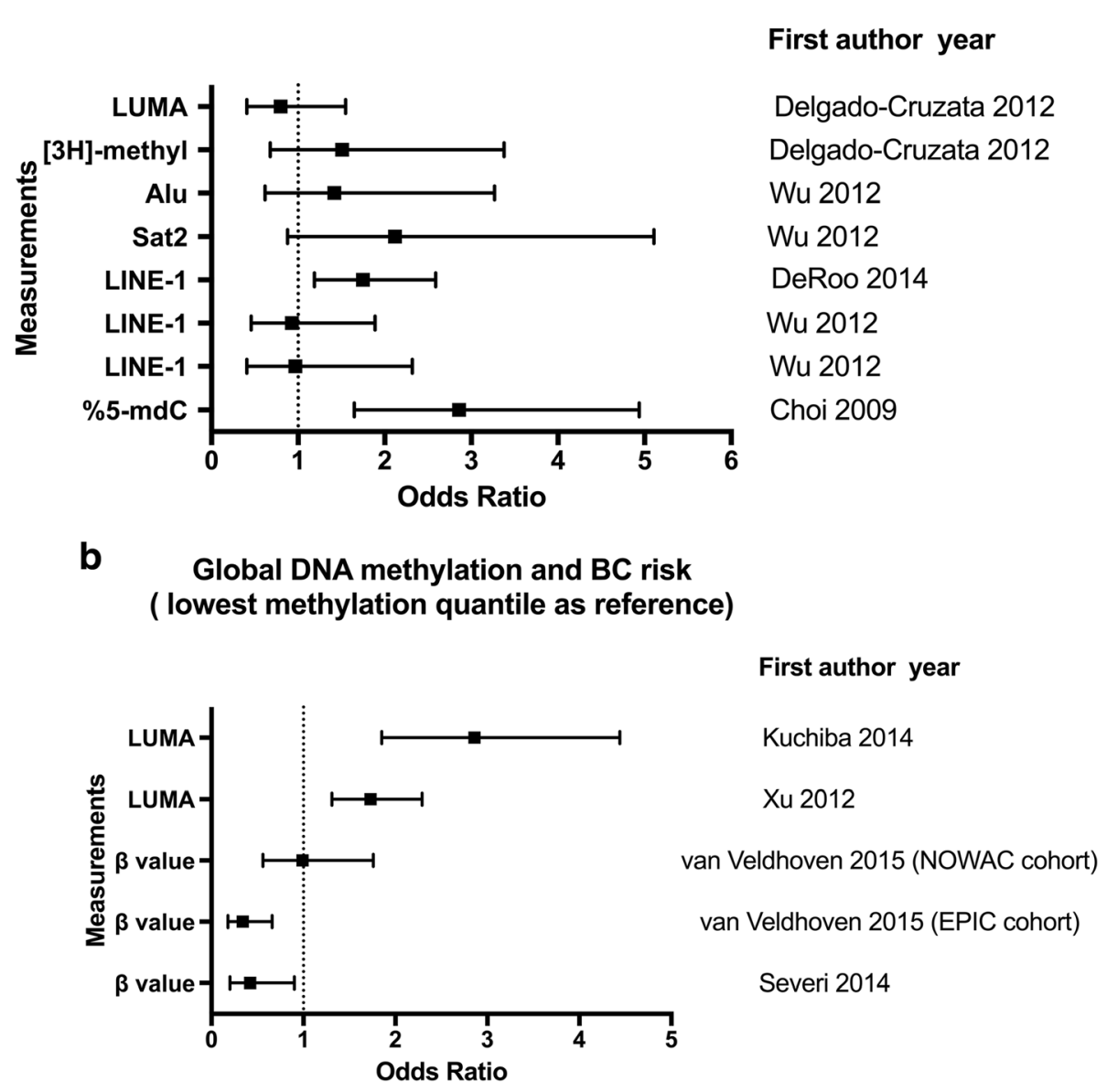

Fig. 2 Associations of global DNA methylation in blood and BC risk. a Studies used the highest methylation quantile as reference. b Studies used the lowest methylation quantile as reference

frequently used methods for detection of gene-specific methylation levels were MethyLight and pyrosequencing. $B R C A 1$ was investigated in seven studies and thus the most frequently investigated gene [16, 20, 24, 27, 30, 37, 39]. Importantly, all these studies reported a rather higher frequency of methylated $B R C A 1$ in $\mathrm{BC}$ cases than in healthy controls, although the differences were only statistically significant in four studies [16, 20, 24, 37]. $A T M$ was investigated in two studies [15, 17], and both of them observed hypermethylation of $A T M$ in $\mathrm{BC}$ patients. Methylation levels of IGF2 [25, 41], CDH1 [39, 42], SYK [14, 42], RARB [27, 39], APC $[27,42]$, and RASSF1A [27, 42] were found similar between $\mathrm{BC}$ patients and controls in two or more studies. Methylation of ESR [14, 42] and TIMP3 [14, 42] were also determined in more than one study, while the methylation differences of these genes between blood DNA of BC cases and controls were not conclusive. Other genes investigated in only one study were summarized in Additional file 1: Table S1.

Figure 3 shows the associations of gene-specific methylation in blood and BC risk. Yang et al. [21] showed that reduced methylation levels of the HYAL2 gene were significantly associated with increased $B C$ risk. Specifically, women in the highest quartile of HYAL2 methylation were reported to have a 41.47 -fold (cohort I) and a 132.98-fold (cohort II) increased BC risk, compared with women in the lowest quartile (Fig. 3a). Hypermethylation of ATM and increased BC risk were observed in two studies $[15,17]$. Here, the lowest methylation quantile was used as reference (Fig. 3b). Hoffman et al. observed a negative association between CLOCK methylation and BC risk [28] (Fig. 3b). Widschwendter et al. investigated methylation of a few genes in a case-control study $(n=1083)$ and found that decreased DNA methylation in NUP155 (I), ZNF217 (II), 
Table 3 Gene-specific methylation in peripheral blood DNA in breast cancer cases and controls investigated in more than one study

\begin{tabular}{|c|c|c|c|c|c|c|c|c|}
\hline Gene & 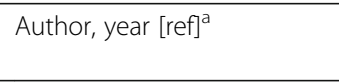 & Assay (value) & $\begin{array}{l}\text { Case } \\
\text { no./control no. }\end{array}$ & $\begin{array}{l}\text { Case age/control } \\
\text { age }(y)^{b}\end{array}$ & Meth (case) & Meth (control) & $p$ value & Main findings \\
\hline \multirow[t]{7}{*}{ BRCA1 } & Cho YH, 2015 [39] & MethyLight (\%) & 1021/1036 & $\mathrm{na} / \mathrm{na}$ & 12 & 10 & $>0.05$ & \multirow{7}{*}{$\begin{array}{l}\text { Higher frequency of methylated } \\
B R C A 1 \text { in } B C \text { patients was observed } \\
\text { in all six studies. }\end{array}$} \\
\hline & Gupta S, 2014 [37] & MS-HRM (\%) & $66 / 36$ & $48.8 / 56.1$ & 22.7 & 5.6 & 0.03 & \\
\hline & Bosviel R, 2012 [30] & QMSP (\%) & $902 / 990$ & $47.1 / 45.9$ & $47.1(46.1-48.1)$ & $45.9(45.0-46.8)$ & 0.08 & \\
\hline & Wong EM, 2011 [20] & MS-HRM (\%) & $255 / 169$ & $<40 /<40$ & 10.9 & 3.6 & 0.004 & \\
\hline & Iwamoto T, 2011 [16] & MSP (\%) & $200 / 200$ & $50 / 50$ & 21.5 & 13.5 & 0.045 & \\
\hline & Cho YH, 2010 [27] & MethyLight (\%) & $40 / 40$ & $50.8 / 48.3$ & 8 & 5 & $>0.05$ & \\
\hline & Snell C, 2008 [24] & MethyLight (\%) & $7 / 7$ & $35-51 / 35-51$ & 42.9 & 14.3 & $<0.05$ & \\
\hline \multirow[t]{9}{*}{ ATM } & \multirow[t]{8}{*}{ Brennan K, 2012 [17] } & Pyrosequencing ATM (mvp2a) & & & & & & \multirow{9}{*}{$\begin{array}{l}\text { Hypermethylation of ATM (intragenic } \\
\text { repetitive element) in BC patients was } \\
\text { observed in two studies. }\end{array}$} \\
\hline & & BGS cohort (mean and IQR) & $249 / 248$ & $54 / 54$ & $76.8(70.9-82.7)$ & $76.4(70.2-80.2)$ & 0.02 & \\
\hline & & EPIC cohort (mean and IQR) & $235 / 283$ & $52 / 52$ & $75.7(70.0-80.8)$ & $76.1(70.5-80.6)$ & 0.4 & \\
\hline & & KConFab cohort (mean and IQR) & $156 / 210$ & $50 / 60$ & $81.8(75.8-86.5)$ & $76.9(71.6-81.5)$ & $4.87 \times 10^{-6}$ & \\
\hline & & Pyrosequencing ATM (mvp2b) & & & & & & \\
\hline & & BGS cohort (mean and IQR) & $248 / 234$ & $54 / 54$ & $91.4(85.6-95.0)$ & $91.0(87.0-94.8)$ & 0.61 & \\
\hline & & EPIC cohort (mean and IQR) & $240 / 287$ & $52 / 52$ & $92.3(88.3-95.7)$ & $92.2(87.3-95.2)$ & 0.36 & \\
\hline & & KConFab cohort (mean and IQR) & $162 / 208$ & $50 / 60$ & $92.3(82.4-96.5)$ & $92.6(87.2-96.3)$ & 0.24 & \\
\hline & Flanagan JM, 2009 [15] & Pyrosequencing (mean and IQR) & 190/190 & $62.8 / 62.8$ & $91.4(72.8-98.4)$ & $89.8(53.0-98.0)$ & 0.002 & \\
\hline \multirow[t]{4}{*}{ IGF2 } & Harrison K, 2015 [41] & Pyrosequencing (mean $\pm \mathrm{SD}$ ) & $189 / 363$ & $56 / 56$ & $48.94 \pm 5.61$ & $48.15 \pm 5.77$ & 0.123 & \multirow{4}{*}{$\begin{array}{l}\text { Two studies reported no significant } \\
\text { differences in methylation of IGF2 } \\
\text { between BC cases and healthy controls }\end{array}$} \\
\hline & Ito Y, 2008 [25] & $\begin{array}{l}\text { Pyrosequencing } \\
\text { (\% of loss of methylation) }\end{array}$ & & & & & & \\
\hline & & EPIC-Norfolk cohort & $228 / 460$ & $60.5 / 60.3$ & 6.6 & 6.3 & 0.91 & \\
\hline & & $A B C$ cohort & $338 / 84$ & $52.6 / 43.2$ & 5.6 & 7.1 & 0.65 & \\
\hline \multirow[t]{3}{*}{$\mathrm{CDH} 1$} & Cho YH, 2015 [39] & MethyLight (\%) & 1021/1036 & na/na & 58 & 66 & $>0.05$ & \multirow{3}{*}{$\begin{array}{l}\text { Three studies observed no significant } \\
\text { differences in methylation of } \mathrm{CDH} 1 \\
\text { between } \mathrm{BC} \text { cases and controls. }\end{array}$} \\
\hline & Zmetakova I, 2013 [42] & Pyrosequencing (mean $\pm \mathrm{SD}$ ) & $34 / 50$ & $41-90 / 20-78$ & $9.64 \pm 2.10$ & $9.02 \pm 1.60$ & 0.698 & \\
\hline & Cho YH, 2010 [27] & MethyLight (\%) & $40 / 40$ & $50.8 / 48.3$ & 8 & 8 & $>0.05$ & \\
\hline \multirow[t]{2}{*}{ ESR1 } & Zmetakova I, 2013 [42] & Pyrosequencing (mean $\pm S D)$ & $34 / 50$ & $41-90 / 20-78$ & $4.09 \pm 1.44$ & $3.22 \pm 0.86$ & 0.026 & \multirow{2}{*}{$\begin{array}{l}\text { Zmetakova I et al. reported higher } \\
\text { methylation of ESR1 in patients, while } \\
\text { Widschwendter. } M \text { et al. observed no } \\
\text { significant difference. }\end{array}$} \\
\hline & Widschwendter M, 2008 [14] & MethyLight (\%) & $320 / 676$ & $50-74 / 50-74$ & 12.2 & 13.5 & 0.645 & \\
\hline \multirow[t]{2}{*}{ SYK } & Zmetakova I, 2013 [42] & Pyrosequencing (mean $\pm S D)$ & $34 / 50$ & $41-90 / 20-78$ & $1.15 \pm 0.44$ & $1.06 \pm 0.24$ & 0.638 & \multirow{2}{*}{$\begin{array}{l}\text { Both studies observed no significant } \\
\text { differences in methylation of SYK } \\
\text { between BC cases and controls. }\end{array}$} \\
\hline & Widschwendter M, 2008 [14] & MethyLight (\%) & $320 / 676$ & $50-74 / 50-74$ & 2.2 & 2.4 & 0.889 & \\
\hline \multirow[t]{2}{*}{ TIMP3 } & Zmetakova I, 2013 [42] & Pyrosequencing & $34 / 50$ & $41-90 / 20-78$ & $3.65 \pm 2.55$ & $2.50 \pm 0.81$ & 0.036 & \multirow{2}{*}{$\begin{array}{l}\text { Zmetakova I et al. reported higher } \\
\text { methylation of TIMP3 in patients, while } \\
\text { Widschwendter. M et al. observed no } \\
\text { significant difference. }\end{array}$} \\
\hline & Widschwendter M, 2008 [14] & MethyLight (\%) & $320 / 676$ & $50-74 / 50-74$ & 12.5 & 14.2 & 0.511 & \\
\hline
\end{tabular}


Table 3 Gene-specific methylation in peripheral blood DNA in breast cancer cases and controls investigated in more than one study (Continued)

\begin{tabular}{|c|c|c|c|c|c|c|c|c|}
\hline \multirow[t]{2}{*}{$R A R B$} & Cho YH, 2015 [39] & MethyLight (\%) & 1021/1036 & na/na & 33 & 39 & $>0.05$ & \multirow{2}{*}{$\begin{array}{l}\text { Two studies reported no significant } \\
\text { differences in methylation of RARB } \\
\text { between } B C \text { cases and healthy controls. }\end{array}$} \\
\hline & Cho YH, 2010 [27] & MethyLight (\%) & $40 / 40$ & $50.8 / 48.3$ & 10 & 10 & $>0.05$ & \\
\hline \multirow[t]{2}{*}{$A P C$} & Zmetakova I, 2013 [42] & Pyrosequencing (mean $\pm \mathrm{SD}$ ) & $34 / 50$ & $41-90 / 20-78$ & $1.68 \pm 1.04$ & $1.28 \pm 0.57$ & 0.082 & \multirow{2}{*}{$\begin{array}{l}\text { Two studies reported no significant } \\
\text { differences in methylation of } A P C \\
\text { between } B C \text { cases and healthy controls. }\end{array}$} \\
\hline & Cho YH, 2010 [27] & MethyLight (\%) & $40 / 40$ & $50.8 / 48.3$ & 0 & 0 & $>0.05$ & \\
\hline \multirow[t]{2}{*}{ RASSFIA } & Zmetakova I, 2013 [42] & Pyrosequencing (mean $\pm \mathrm{SD}$ ) & $34 / 50$ & $41-90 / 20-78$ & $1.00 \pm 0.00$ & $1.04 \pm 0.28$ & 0.475 & \multirow{2}{*}{$\begin{array}{l}\text { Two studies reported no significant } \\
\text { differences in methylation of RASSF1A } \\
\text { between BC cases and healthy controls. }\end{array}$} \\
\hline & Cho YH, 2010 [27] & MethyLight (\%) & $40 / 40$ & $50.8 / 48.3$ & 8 & 3 & $>0.05$ & \\
\hline
\end{tabular}

${ }^{a}$ All studies were case-control study

${ }^{\mathrm{b}}$ Age indicates mean age or range 


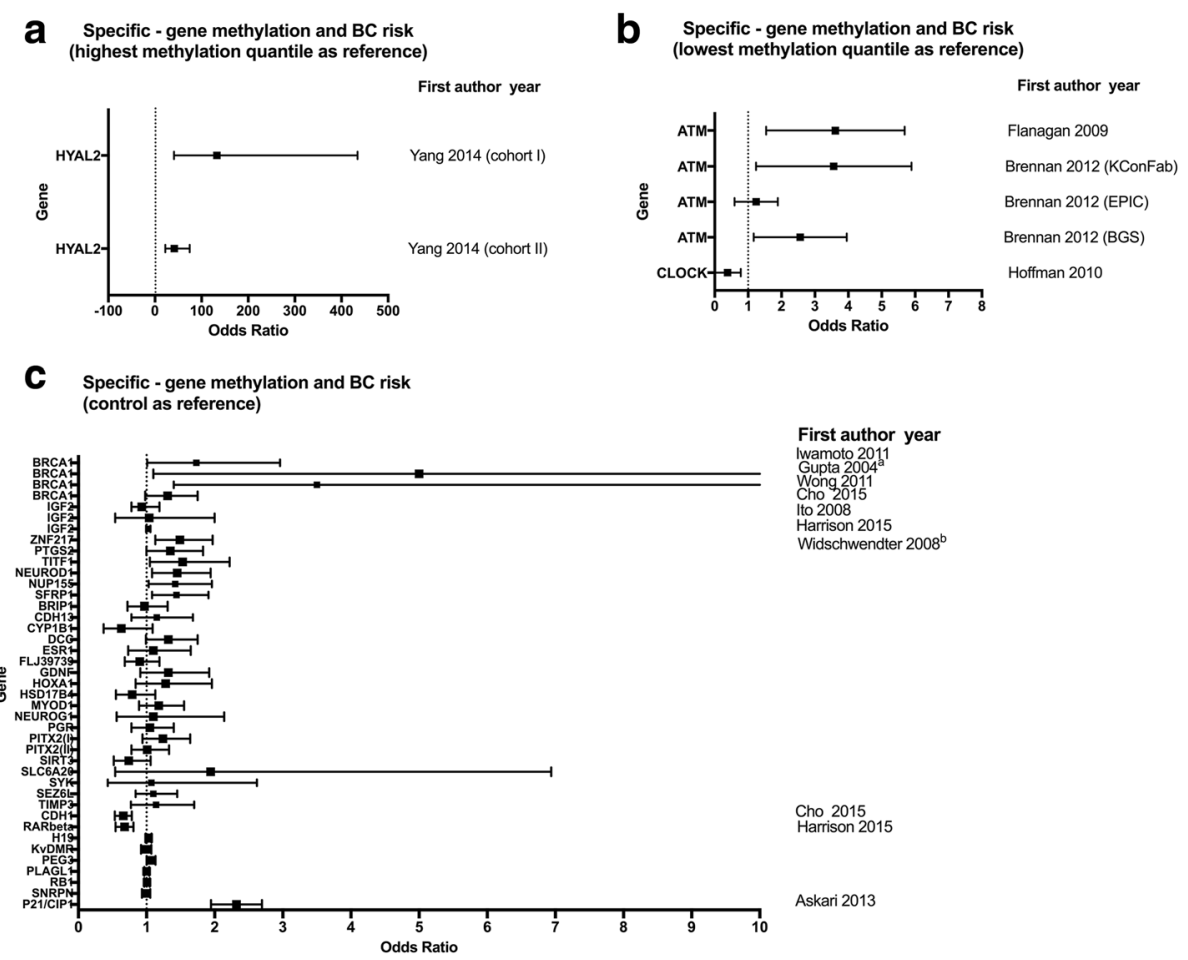

Fig. 3 Associations of gene-specific methylation in blood and BC risk. a Studies used the highest methylation quantile as reference. $\mathbf{b}$ Studies used the lowest methylation quantile as reference. c Studies used methylation of controls as reference. ${ }^{\text {aThe }}$ upper limit of $95 \% \mathrm{Cl}$ of the study of Gupta was over ten. 'Widschwendter M and coauthors investigated the genes from ZNF217 to TIMP3

PTGS2, TITF1, NEUROD1, and SFRP1 are associated with increased BC risk [14] (Fig. 3c). Hypermethylation of $B R C A 1$ promoter was associated with increased $\mathrm{BC}$ risk, which was confirmed in two independent studies $[16,37]$ (Fig. 3c).

\section{Gene-specific methylation in cfDNA from serum or plasma of $\mathrm{BC}$ cases and controls}

Table 4 summarizes all studies that investigated methylation differences of specific genes in serum or plasma DNA of BC cases and healthy controls. Studies conducted by Yazici et al. [46] and Brooks et al. [56] were nested case-control studies and the remaining studies were all case-control studies. Generally, the sample sizes were rather low. Case number varied from 4 to 250. All eligible studies using serum or plasma DNA investigated DNA methylation levels at specific loci, rather than global DNA methylation levels. Further, so far no epigenome-wide study has been performed on cfDNA. This can be explained by the technical difficulties due to the specific characteristics, such as strongly fragmented DNA and reduced DNA integrity especially in cancer cases [61]), and limited amounts of cfDNA that can be isolated from serum or plasma [62-64], and also to uncertainties regarding its origins [65]. The most common method used to measure the methylation levels of specific genes in serum or plasma cfDNA was methylation-specific PCR (MSP) (Table 4 and Additional file 1: Table S2).

Most of these studies investigated tumor suppressor genes and frequently reported the hypermethylation of these genes in $\mathrm{BC}$ patients (Table 4 and Additional file 1: Table S2). With ten studies, RASSF1A was the most frequently evaluated gene and eight of them reported higher frequency of methylated RASSF1A in BC patients compared to controls [42, 44-46, 50, 52, 55-58]. APC has been investigated in seven studies [42, 44, 47, 50, 52, 56, 59]. Among them, five studies reported higher frequency of methylated $A P C$ in plasma/serum DNA of $B C$ patients. Higher frequency of methylated $R A R B$ (also known as $R A R \beta 2$ ) was observed in four studies [44, 56, 57, 59]. Methylation levels of ESR1 [42, 51, 52, 54], GSTP1 [44, 47, 56], and TIMP3 [42, 47] were each investigated in two or more studies, but each gene yielded with inconclusive results. Hypermethylation of SFN (also known as stratifin or 14-3-3- $\sigma$ ) [51, 54], BRCA1 [47, 60], CST6 $[47,49]$, and DAPK $[49,50]$ were confirmed in two independent studies, respectively (Table 4). Brooks J.D. et al. [56] reported no significant differences in the methylation of all four genes (RASSF1A, GSTP1, APC, and RARB) investigated between $B C$ cases and controls. It is worth to point out that the DNA amounts used in this study were 
Table 4 Gene-specific methylation in serum or plasma DNA in breast cancer cases and controls investigated in more than one study

\begin{tabular}{|c|c|c|c|c|c|c|c|c|c|}
\hline Gene & Author, year [ref] & Sample & Assay (value) & $\begin{array}{l}\text { Case } \\
\text { no./control no. }\end{array}$ & $\begin{array}{l}\text { Case age/control } \\
\text { age }(y)^{b}\end{array}$ & Meth (case) & Meth (control) & $p$ value & Main findings \\
\hline \multirow[t]{10}{*}{ RASSFIA } & Kloten V, 2013 [58] & Serum & MS-PCR (\%) & $136 / 135$ & $33-86 / 33-86$ & 47.1 & 25.9 & 0.004 & \multirow{10}{*}{$\begin{array}{l}\text { Higher frequency of methylated RASSFIA } \\
\text { was observed in eight studies. Studies by } \\
\text { Zmetakova I et al. and Brooks JD et al. } \\
\text { reported no significant differences in } \\
\text { methylation of RASSF1A between cases } \\
\text { and controls }\end{array}$} \\
\hline & Zmetakova I, 2013 [42] & Plasma & Pyrosequencing (mean \pm SD) & $34 / 50$ & $41-90 / 20-78$ & $2.85 \pm 3.13$ & $4.02 \pm 6.62$ & 0.404 & \\
\hline & Ahmed IA, 2010 [55] & Serum & MSP (\%) & $26 / 12$ & $35-73 / 35-73$ & 69 & $<10$ & - & \\
\hline & Brooks JD, $2010[56]^{d}$ & Serum & QMSP (\%) & $50 / 99$ & $52 / 51.8$ & 22 & 17.2 & $>0.05$ & \\
\hline & Kim JH, 2010 [57] & Serum & QMSP (\%) & $119 / 125$ & $51 / 51$ & 32.8 & 4.8 & 0.004 & \\
\hline & Yazici H, $2009[46]^{d}$ & Plasma & MSP (\%) & $61 / 39$ & na/na & 18 & 5 & - & \\
\hline & Hoque M, 2006 [44] & Plasma & QMSP (\%) & $47 / 38$ & $44.9 / 37.3$ & 32 & 5 & 0.002 & \\
\hline & Van der Auwera I, 2009 [52] & Serum & QMSP (\%) & $79 / 19$ & $62 / 39$ & 35 & 0 & 0.002 & \\
\hline & Papadopoulou E, 2006 [45] & Plasma & Methylight (\%) & $50 / 14$ & na/na & 26 & 0 & $<0.05$ & \\
\hline & Dulaimi E, 2004 [50] & Serum & MSP (\%) & $34 / 20$ & $57.4 / 57.4$ & 56 & 0 & $<0.05^{\mathrm{c}}$ & \\
\hline \multirow[t]{7}{*}{$A P C$} & Swellam M, 2015 [59] & Serum & MS-PCR (\%) & $121 / 66$ & $43 / 40$ & 93.4 & 0 & $<0.0001$ & \multirow{7}{*}{$\begin{array}{l}\text { Five out of these seven studies reported } \\
\text { higher frequency of methylated APC in } \\
\text { BC patients. Studies by Zmetakova I et al. } \\
\text { and Brooks JD et al. reported no significant } \\
\text { differences in methylation of APC between } \\
\text { cases and controls. }\end{array}$} \\
\hline & Zmetakova I, 2013 [42] & Plasma & Pyrosequencing (mean $\pm \mathrm{SD}$ ) & $34 / 50$ & $41-90 / 20-78$ & $4.41 \pm 7.81$ & $2.53 \pm 1.56$ & 0.06 & \\
\hline & Radpour R, 2011 [47] & Plasma & EpiTyper assay (mean) & $36 / 30$ & $67 /$ na & $0.39^{b}$ & $0.19^{\mathrm{b}}$ & $<0.0001$ & \\
\hline & Brooks JD, $2010[56]^{d}$ & Serum & QMSP (\%) & $49 / 96$ & $52 / 51.8$ & 2 & 4.2 & $>0.05$ & \\
\hline & Hoque M, 2006 [44] & Plasma & QMSP (\%) & $47 / 38$ & $44.9 / 37.3$ & 17 & 0 & 0.008 & \\
\hline & Van der Auwera I, 2009 [52] & Serum & QMSP (\%) & $79 / 19$ & $62 / 39$ & 29 & 5 & 0.03 & \\
\hline & Dulaimi E, 2004 [50] & Serum & MSP (\%) & $34 / 20$ & $57.4 / 57.4$ & 29 & 0 & $<0.05^{c}$ & \\
\hline \multirow[t]{4}{*}{ ESR1 } & Zmetakova I, 2013 [42] & Plasma & Pyrosequencing (mean $\pm \mathrm{SD}$ ) & $34 / 50$ & $41-90 / 20-78$ & $4.18 \pm 4.07$ & $5.24 \pm 4.33$ & 0.338 & \multirow{4}{*}{$\begin{array}{l}\text { Only one study (Matinez-Galan, J) reported } \\
\text { higher methylation levels of ESR1 in BC } \\
\text { patients. Others observed no significant } \\
\text { methylation differences. }\end{array}$} \\
\hline & Zurita M, 2010 [54] & Serum & QMSP (\%) & $77 / 34$ & na/na & $0.005^{\mathrm{b}}$ & $0.085^{\mathrm{b}}$ & $>0.05$ & \\
\hline & Van der Auwera I, 2009 [52] & Serum & QMSP (\%) & $79 / 19$ & $62 / 39$ & 20 & 10.5 & 0.33 & \\
\hline & Martinez-Galan J, 2008 [51] & Serum & MSP (\%) & $106 / 74$ & $58 / 42$ & $0.11^{b}$ & $0.02^{\mathrm{b}}$ & 0.011 & \\
\hline \multirow[t]{4}{*}{ RARB } & Swellam M, 2015 [59] & Serum & MS-PCR (\%) & $121 / 66$ & $43 / 40$ & 95.9 & 0 & $<0.0001$ & \multirow{4}{*}{$\begin{array}{l}\text { Higher frequency of methylated RARB } \\
\text { was observed except the study conducted } \\
\text { by Brooks JD et al. }\end{array}$} \\
\hline & Brooks JD, $2010[56]^{d}$ & Serum & QMSP (\%) & $45 / 88$ & $52 / 51.8$ & 6.7 & 1.1 & $>0.05$ & \\
\hline & Kim JH, 2010 [57] & Serum & QMSP (\%) & $119 / 125$ & $51 / 51$ & 86.6 & 6.4 & $<0.001$ & \\
\hline & Hoque M, 2006 [44] & Plasma & QMSP (\%) & $47 / 38$ & $44.9 / 37.3$ & 26 & 8 & 0.03 & \\
\hline \multirow[t]{3}{*}{ GSTP1 } & Radpour R, 2011 [47] & Plasma & EpiTyper assay (mean) & $36 / 30$ & $67 /$ na & $0.52^{\mathrm{b}}$ & $0.39^{b}$ & 0.003 & \multirow{3}{*}{$\begin{array}{l}\text { Two studies reported higher methylation } \\
\text { level (Radpour R et al., 2011) or frequency } \\
\text { (Hoque M et al., 2006) of GSTP1 in BC } \\
\text { patients. Study by Brooks.J.D observed no } \\
\text { significant differences. }\end{array}$} \\
\hline & Brooks JD, $2010[56]^{d}$ & Serum & QMSP (\%) & $50 / 99$ & $52 / 51.8$ & 4 & 7.1 & $>0.05$ & \\
\hline & Hoque M, 2006 [44] & Plasma & QMSP (\%) & $47 / 38$ & $44.9 / 37.3$ & 26 & 0 & 0.0008 & \\
\hline \multirow[t]{2}{*}{ SFN } & Zurita M, 2010 [54] & Serum & QMSP (\%) & $77 / 34$ & na/na & $0.002^{b}$ & $0.1^{b}$ & $<0.001$ & \multirow{2}{*}{$\begin{array}{l}\text { Both studies reported higher methlyation } \\
\text { of SFN in BC patients. }\end{array}$} \\
\hline & Martinez-Galan J, 2008 [51] & Serum & MSP (\%) & $106 / 74$ & $58 / 42$ & $0.20^{\mathrm{b}}$ & $0.075^{b}$ & 0.0047 & \\
\hline$B R C A 1$ & Liu LM, 2015 [60] & Serum & $\begin{array}{l}\text { Bisulfite sequencing } \\
\text { PCR and MS-HRM (\%) }\end{array}$ & $36^{\mathrm{a}} / 30^{\mathrm{a}}$ & na/na & 10 & 1.7 & $<0.05$ & $\begin{array}{l}\text { Both studies reported higher methlyation } \\
\text { of } B R C A 1 \text { in } B C \text { patients }\end{array}$ \\
\hline
\end{tabular}


Table 4 Gene-specific methylation in serum or plasma DNA in breast cancer cases and controls investigated in more than one study (Continued)

\begin{tabular}{|c|c|c|c|c|c|c|c|c|c|}
\hline & Radpour R, 2011 [47] & Plasma & EpiTyper assay & $36 / 30$ & $67 /$ na & $0.58^{\mathrm{b}}$ & $0.30^{b}$ & $<0.0001$ & \\
\hline \multirow[t]{2}{*}{ CST6 } & Chimonidou M, 2013 [49] & Plasma & MSP (\%) & $73 / 37$ & $\mathrm{na} / \mathrm{na}$ & 16.4 & 0 & & \multirow{2}{*}{$\begin{array}{l}\text { ChimonidouM et al. reported that CST6 } \\
\text { promoter is highly methylated in cfDNA of } \\
\text { breast cancer patients, but not in healthy } \\
\text { individuals. Radpour R et al. observed higher } \\
\text { methlytion level of CST6 in BC patients. }\end{array}$} \\
\hline & Radpour R, 2011 [47] & Plasma & EpiTyper assay (mean) & $36 / 30$ & $67 /$ na & $0.62^{\mathrm{b}}$ & $0.42^{\mathrm{b}}$ & $<0.002$ & \\
\hline \multirow[t]{2}{*}{ DAPK } & Ahmed IA, 2010 [55] & Serum & MSP (\%) & $26 / 12$ & $35-73 / 35-73$ & 88 & $<10 \%$ & $<0.05$ & \multirow{2}{*}{$\begin{array}{l}\text { Higher frequency of methylated DAPK in } \\
\text { patients was observed in both studies. }\end{array}$} \\
\hline & Dulaimi E, 2004 [50] & Serum & MSP & $34 / 20$ & $57.4 / 57.4$ & 35 & 0 & $<0.05^{c}$ & \\
\hline \multirow[t]{2}{*}{ TIMP3 } & Zmetakova I, 2013 [42] & Plasma & Pyrosequencing (mean \pm SD) & $34 / 50$ & $41-90 / 20-78$ & $3.97 \pm 8.43$ & $3.92 \pm 4.54$ & 0.697 & \multirow{2}{*}{$\begin{array}{l}\text { Zmetakova I et al. reported no significant } \\
\text { difference in methylation of TIMP3 between } \\
\text { patients and healthy controls. Radpour } \\
\text { R et al. observed higher methylation level } \\
\text { of TIMP3 in BC patients. }\end{array}$} \\
\hline & Radpour R, 2011 [47] & Plasma & EpiTyper assay & $36 / 30$ & $67 /$ na & $0.60^{b}$ & $0.50^{b}$ & $<0.0001$ & \\
\hline
\end{tabular}

MSP methylation-specific PCR, QMSP quantitative methylation-specific PCR, MS-HRM methylation-sensitive high-resolution melting, na not available

age indicates mean age or range

${ }^{b}$ Data was extracted from scatter plots or boxplots in the article

${ }^{c} p$ values were calculated by Fisher's exact test

${ }^{\mathrm{d}}$ Nested case-control study; the others are case-control study 
about five times less than the amount hypothetically required to achieve optimal sensitivity and non-specific amplification might occur due to a high number of PCR cycles (i.e., quantitative MSP (QMSP) was run for $50 \mathrm{cy}-$ cles), as the authors discussed in the article. The authors observed lower frequency of methylation than expected among cases and higher than expected among controls in this study as compared to other studies (review in [66]), which might be the reasons for the negative results. Other genes, which were investigated in only one study, were summarized in Additional file 1: Table S2.

\section{Discussion}

Our literature review identified 45 articles investigating blood-based DNA methylation markers for BC detection or risk evaluation, with DNA isolated from whole blood or from serum or plasma. In this systematic review, we summarized the differences in epigenome-wide DNA methylation levels or gene-specific methylation that were between $\mathrm{BC}$ patients and healthy females in all these studies. In particular, several large nested or respective case-control studies were conducted in recent years. This could be partly attributed to the novel emerging techniques, such as Infinium Humanmethylation 27K or $450 \mathrm{~K}$ array or whole genome bisulfite sequencing (WGBS), which are effective ways to screen for and identify large numbers of methylation markers.

Even though whole blood DNA presents a mixture of leucocytes subtypes, DNA methylation from whole blood samples seems to be promising reservoir for informative biomarkers for $\mathrm{BC}$ risk stratification. Two nested case-control studies have concluded that such genomic hypomethylation continuum can be evident at blood DNA level and may identify high-risk women before developing BC $[18,19]$. Some retrospective casecontrol studies also reported that cancer patients have lower global methylation levels in blood DNA compared to controls (Table 2). As blood DNA can be assessed easily, its epigenetic effects on cancer propensity could be repeatedly examined in specified time intervals.

Repetitive DNA sequences (e.g., LINE-1, Alu, and Sat2) are all comparatively rich in $\mathrm{CpG}$ dinucleotides and contain a large portion of total methylcytosine levels in the genome $[67,68]$. In this regard, some researchers suggested that repetitive elements in blood DNA might be surrogate for genomic hypomethylation. Studies of BC, however, have yielded heterogeneous results (Table 2). Choi et al. [26] found decreased methylation of 5-mdC in blood DNA of women with BC compared to controls; meanwhile, $\mathrm{Wu} \mathrm{HC}$ et al. [31] and Cho et al. [27] found decreased methylation of Sat2 in BC patients. Xu et al. [29], however, found increased global methylation among cases using the luminometric methylation assay. In the study of Choi et al., LINE-1 methylation and \%5-mdC were not correlated, and only hypomethylation quantified as \%5-mdC level was significantly associated with $\mathrm{BC}$ risk [26]. The inconsistencies between results in $B C$ patients and normal females probably arise from different detection targets, using different techniques and/or from differential distributions of clinical characteristics.

In the implementation and interpretation of studies based on blood samples, a potential limitation deserving particular attention is that differences in methylation profiles might also reflect differences in the proportions of the leukocyte subpopulations that make up the whole blood $[69,70]$. Hence, the majority of EWASs adjusted their analysis for leucocyte distribution with the algorithm of Houseman et al. [69]. Nevertheless, even if BC-related methylation patterns were partly due to confounding by leucocyte distribution, they might still be useful as biomarkers of $\mathrm{BC}$.

Circulating cfDNA is defined as extracellular DNA occurring in blood. Both plasma and serum are cell-free blood specimens that were used for the determination of cfDNA. Silencing of tumor suppressor genes by promoter hypermethylation is known to be a frequent and early event in carcinogenesis [11]. Further, changes in methylation patterns observed in tumors are also detectable in cfDNA of women with $\mathrm{BC}$ and showed good concordance [50, 71-74]. This makes the possibility of using these alterations candidate markers for early tumor detection. Among all the identified studies in our review, the largest number of studies was found for $B R C A 1$ and RASSF1A, for which higher frequencies of methylated BRCA1 and RASSF1A in BC patients than in healthy females were reported rather consistently. Other tumor suppressor genes, such as APC, RARB, GSTP1, $D A P K$, and $S F N$ were also found more frequently methylated in BC cases than in controls. Methylation-specific PCR was the most frequently employed method in the studies evaluating the methylation of specific genes in whole blood and plasma/serum.

Circulating cfDNA, presumably shed from the original primary tumor, can be retrieved and tested for genetic and epigenetic alterations. However, so far, little is known about the relationship between detection of epigenetic abnormalities in primary $\mathrm{BC}$ tissue and detection of such abnormalities in plasma or serum. In addition, the amount of cfDNA is around $5-20 \mathrm{ng} / \mathrm{ml}$ in the circulation of a normal individual $[62,75]$, which strongly depends on the accurate sample processing [61]. This could be the main obstacle in finding tumor-specific differences in sera/ plasma and the main reason of the lack of sensitivity of the epigenetic biomarkers studied [42]. cfDNA may be released to the circulation via passive release as a result of cellular apoptosis and necrosis and/or active secretion from live cells. The cfDNA can comprise long fragments or shorter fragments ranging from around 20 to $20 \mathrm{~kb}$, 
depending on their mechanism of release into the circulation [63, 64]. It has been shown by experiments on fetal DNA in the maternal circulation that the half-life of free DNA in blood is only around $16 \mathrm{~min}$ [76]. The limited amount, intrinsic characteristics, and short half-life of cell-free DNA could partly explain that for the markers evaluated in more than one study, the methylation differences between cases and controls are not consistent and sometimes varied greatly across studies. The discrepancy probably could also arise from diverse study design, use of different sources of DNA, and/or from differential distributions of clinical characteristics.

Changes in DNA methylation profiles, both at overall genomic level and specific loci, have been associated with BC risk (Fig. 2 and Fig. 3). Among all the studies included in the present review, in total, eight studies measured overall WBC global DNA methylation and BC risk (Fig. 2). Four of these studies [18, 19, 26, 38] have found a significant elevated risk for BC between those in the lowest quantile of global DNA methylation compared to those in the highest methylation quantile. However, Kuchiba A et al. [36] and Xu X et al. [29] found a positive association between LUMA methylation and increased $\mathrm{BC}$ risk. The few studies investigating the gene-specific methylation in blood DNA also supported the potential for gene-specific methylation as biomarkers for risk (Fig. 3). However, research in this field is still at an early stage. So far, the number of studies that conducted epigenome-wide studies to detect $\mathrm{BC}$ associated genes is very limited. More evidence, including both genome-wide hypomethylation level and gene-specific hypo- and hypermethylation and $\mathrm{BC}$ risk, is still needed to collect.

$\mathrm{BC}$ is a highly heterogeneous disease. Many of the established risk factors are linked to the development of the disease. The highest risk factor for sporadic BC is increasing age. The incidence of $\mathrm{BC}$ in women doubles for every 10 years until menopause with a relative risk of $>10$-fold [77]. Because promoter hypermethylation may be related to age, studies investigating a potential diagnostic utility for methylated genes should have a reasonable number of age-matched controls. While some authors chose an age-matched control group, others did not and the age difference between cases and controls was often rather large. For example, Zmetakova I et al. [42] compared BC patients with age range between 41 and 90 years with healthy blood donors of considerably younger age (range 20-78). The control group of the study conducted by Ito $\mathrm{Y}$ et al. [25] even had an average of 43.2, which is almost 10 years younger than the mean age of $\mathrm{BC}$ patients (52.6) they included. Thus, the observed methylation differences and associations between methylation changes and $\mathrm{BC}$ risk might be confounded by age.
To our knowledge, this is the first review to systematically and comprehensively review and summarize results of epidemiological studies on the association of DNA methylation in blood with $\mathrm{BC}$. In the interpretation of this review, some limitations have to be considered. Although two widely used databases were searched and crossreferencing of identified articles was applied, we cannot exclude having missed relevant studies. Furthermore, studies were reported in a rather heterogeneous manner, which limited possibilities of a standardized summary of the results. Because of the heterogeneous nature of the included studies and the fact that quite a few markers were evaluated in single studies only, we did not conduct metaanalyses and our tables only provide a narrative summary of the reported methylation differences.

\section{Conclusions}

Our review suggests the possibility of using blood-based methylation markers for risk stratification or the early detection of $\mathrm{BC}$, as a number of studies support an association between methylation changes in blood and $\mathrm{BC}$ risk, irrespective of full understanding of the pathophysiological mechanisms. However, the evidence is still very limited. Optimized marker panels are yet to be developed and promising candidate markers needed to be validated in prospective study cohorts and tested in large screening populations by high quality studies. In addition, there is a strong need for large, methodologically rigorous epidemiological studies to figure out the potential role of methylation changes in blood in breast carcinogenesis and their implications for detection. Especially, the investigation of methylation changes in cfDNA holds great promises. Here, optimization of methods for genome-wide methylation analysis of small amounts of DNA is needed.

\section{Additional file}

Additional file 1: Table S1. Gene-specific methylation in peripheral blood in breast cancer cases and controls investigated in only one study. Table S2. Specific-gene methylation in serum or plasma DNA in breast cancer cases and controls investigated in only one study. Supplementary materials. Exclusion reasons in full-text selection procedure. (DOCX 96 kb)

\begin{abstract}
Abbreviations
5-mdC: 5-Methyldeoxycytosine; BC: Breast cancer; CA15-3: Cancer antigen 153; CA27-29: Cancer antigen 27-29; cfDNA: Cell-free DNA; LC-MS: Liquid chromatography-mass spectrometry; LINE-1: Long interspersed nuclear element-1; LUMA: Luminometric methylation assay; MSP: Methylation-specific PCR; OR: Odds ratio; QMSP: Quantitative methylation-specific PCR; Sat2: Satellite 2
\end{abstract}

Acknowledgements

We acknowledge the financial support of the Deutsche Forschungsgemeinschaft and Ruprecht-Karls-Universität Heidelberg within the funding program Open Access Publishing. 


\section{Funding}

This study was supported in part by the China Scholarship Council (CSC). The sponsor had no role in the study design and in the collection, analysis, and interpretation of data.

\section{Availability of data and materials}

The datasets supporting the conclusions of this article are included within the article and its Additional file 1.

\section{Authors' contributions}

QT designed the study. QT and JC extracted the data. QT wrote the manuscript. JC, HS, XC, and BB corrected the manuscript. All authors read and approved the final manuscript.

\section{Competing interests}

The authors declare that they have no competing interests.

\section{Consent for publication}

Not applicable.

\section{Ethics approval and consent to participate}

Not applicable.

Received: 24 June 2016 Accepted: 26 October 2016 Published online: 14 November 2016

\section{References}

1. Ferlay J, Soerjomataram I, Dikshit R, Eser S, Mathers C, Rebelo M, et al. Cancer incidence and mortality worldwide: sources, methods and major patterns in GLOBOCAN 2012. Int J Cancer. 2015;136(5):E359-386. doi:10.1002/ijc.29210

2. Siegel R, Naishadham D, Jemal A. Cancer statistics, 2013. CA Cancer J Clin. 2013;63(1):11-30. doi:10.3322/caac.21166.

3. Ludwig JA, Weinstein JN. Biomarkers in cancer staging, prognosis and treatment selection. Nat Rev Cancer. 2005;5(11):845-56. doi:10.1038/nrc1739.

4. Bast Jr RC, Ravdin P, Hayes DF, Bates S, Fritsche Jr H, Jessup JM, et al. 2000 update of recommendations for the use of tumor markers in breast and colorectal cancer: clinical practice guidelines of the American Society of Clinical Oncology. J Clin Oncol. 2001;19(6):1865-78.

5. Claus EB, Schildkraut JM, Thompson WD, Risch NJ. The genetic attributable risk of breast and ovarian cancer. Cancer. 1996;77(11):2318-24. doi:10.1002/ (sici)1097-0142(19960601)77:11<2318::aid-cncr21>3.0.co;2-z.

6. Gradishar WJ, Anderson BO, Balassanian R, Blair SL, Burstein HJ, Cyr A, et al. Invasive breast cancer version 1.2016, NCCN Clinical Practice Guidelines in Oncology. J Natl Compr Canc Netw. 2016;14(3):324-54.

7. Siu AL. Screening for breast cancer: U.S. Preventive Services Task Force Recommendation Statement. Ann Intern Med. 2016:164(4):279-96. doi:10.7326/m15-2886

8. Mukhtar TK, Yeates DR, Goldacre MJ. Breast cancer mortality trends in England and the assessment of the effectiveness of mammography screening: population-based study. J R Soc Med. 2013;106(6):234-42. doi:10.1177/0141076813486779.

9. Marmot M. The benefits and harms of breast cancer screening -an independent review. Br J Cancer. 2013;108(11):2205-40. doi:10.1016/S01406736(12)61611-0

10. Bell RJ. Screening mammography_early detection or over-diagnosis? Contribution from Australian data. Climacteric. 2014;17 Suppl 2:66-72. doi:10.3109/13697137.2014.956718.

11. Hanahan D, Weinberg RA. Hallmarks of cancer: the next generation. Cell. 2011;144(5):646-74. doi:10.1016/j.cell.2011.02.013

12. Li L, Choi J-Y, Lee K-M, Sung H, Park SK, Oze I, et al. DNA methylation in peripheral blood: a potential biomarker for cancer molecular epidemiology. Journal of Epidemiology. 2012;22(5):384-94. doi:10.2188/jea.JE20120003.

13. Jung K, Fleischhacker M, Rabien A. Cell-free DNA in the blood as a solid tumor biomarker - a critical appraisal of the literature. Clinica Chimica Acta. 2010;411(21-22):1611-24. doi:10.1016/j.cca.2010.07.032.

14. Widschwendter M, Apostolidou S, Raum E, Rothenbacher D, Fiegl H, Menon $U$, et al. Epigenotyping in peripheral blood cell DNA and breast cancer risk: a proof of principle study. PLoS One. 2008;3(7):e2656. doi:10.1371/journal. pone.0002656
15. Flanagan JM, Munoz-Alegre M, Henderson S, Tang T, Sun P, Johnson N, et al. Gene-body hypermethylation of ATM in peripheral blood DNA of bilateral breast cancer patients. Hum Mol Genet. 2009;18(7):1332-42. doi:10.1093/hmg/ddp033.

16. Iwamoto T, Yamamoto N, Taguchi T, Tamaki Y, Noguchi S. BRCA1 promoter methylation in peripheral blood cells is associated with increased risk of breast cancer with BRCA1 promoter methylation. Breast Cancer Res Treat. 2011;129(1):69-77. doi:10.1007/s10549-010-1188-1.

17. Brennan K, Garcia-Closas M, Orr N, Fletcher O, Jones M, Ashworth A, et al. Intragenic ATM methylation in peripheral blood DNA as a biomarker of breast cancer risk. Cancer Res. 2012;72(9):2304-13. doi:10.1158/0008-5472. can-11-3157.

18. van Veldhoven K, Polidoro S, Baglietto L, Severi G, Sacerdote C, Panico S, et al. Epigenome-wide association study reveals decreased average methylation levels years before breast cancer diagnosis. Clin Epigenetics. 2015;7(1):67. doi:10.1186/s13148-015-0104-2.

19. Severi G, Southey MC, English DR, Jung CH, Lonie A, McLean C, et al. Epigenome-wide methylation in DNA from peripheral blood as a marker of risk for breast cancer. Breast Cancer Res Treat. 2014;148(3):665-73. doi:10.1007/s10549-014-3209-y.

20. Wong EM, Southey MC, Fox SB, Brown MA, Dowty JG, Jenkins MA, et al. Constitutional methylation of the BRCA1 promoter is specifically associated with BRCA1 mutation-associated pathology in early-onset breast cancer. Cancer Prev Res (Phila). 2011;4(1):23-33. doi:10.1158/1940-6207.capr-10-0212.

21. Yang R, Pfutze K, Zucknick M, Sutter C, Wappenschmidt B, Marme F, et al. DNA methylation array analyses identified breast cancer-associated HYAL2 methylation in peripheral blood. Int J Cancer. 2015;136(8):1845-55. doi:10.1002/ijc.29205.

22. Xu Z, Bolick SC, DeRoo LA, Weinberg CR, Sandler DP, Taylor JA. Epigenomewide association study of breast cancer using prospectively collected sister study samples. J Natl Cancer Inst. 2013;105(10):694-700. doi:10.1093/jnci/djt045.

23. Moher D, Liberati A, Tetzlaff J, Altman DG. Reprint-preferred reporting items for systematic reviews and meta-analyses: the PRISMA statement. Phys Ther. 2009:89(9):873-80.

24. Snell C, Krypuy M, Wong EM, Loughrey MB, Dobrovic A. BRCA1 promoter methylation in peripheral blood DNA of mutation negative familial breast cancer patients with a BRCA1 tumour phenotype. Breast Cancer Res. 2008; 10(1):R12. doi:10.1186/bcr1858.

25. Ito $Y$, Koessler T, Ibrahim AE, Rai S, Vowler SL, Abu-Amero S, et al. Somatically acquired hypomethylation of IGF2 in breast and colorectal cancer. Hum Mol Genet. 2008;17(17):2633-43. doi:10.1093/hmg/ddn163.

26. Choi JY, James SR, Link PA, MCCann SE, Hong CC, Davis W, et al. Association between global DNA hypomethylation in leukocytes and risk of breast cancer. Carcinogenesis. 2009;30(11):1889-97. doi:10.1093/carcin/bgp143.

27. Cho YH, Yazici H, Wu HC, Terry MB, Gonzalez K, Qu M, et al. Aberrant promoter hypermethylation and genomic hypomethylation in tumor, adjacent normal tissues and blood from breast cancer patients. Anticancer Res. 2010;30(7):2489-96.

28. Hoffman AE, Yi CH, Zheng T, Stevens RG, Leaderer D, Zhang Y, et al. CLOCK in breast tumorigenesis: genetic, epigenetic, and transcriptional profiling analyses. Cancer Res. 2010;70(4):1459-68. doi:10.1158/0008-5472.CAN-09-3798.

29. Xu X, Gammon MD, Hernandez-Vargas H, Herceg Z, Wetmur JG, Teitelbaum $S L$, et al. DNA methylation in peripheral blood measured by LUMA is associated with breast cancer in a population-based study. Faseb j. 2012; 26(6):2657-66. doi:10.1096/fj.11-197251.

30. Bosviel R, Garcia S, Lavediaux G, Michard E, Dravers M, Kwiatkowski F, et al. BRCA1 promoter methylation in peripheral blood DNA was identified in sporadic breast cancer and controls. Cancer Epidemiol. 2012;36(3):e177-182. doi:10.1016/j.canep.2012.02.001

31. Wu HC, Delgado-Cruzata L, Flom JD, Perrin M, Liao Y, Ferris JS, et al. Repetitive element DNA methylation levels in white blood cell DNA from sisters discordant for breast cancer from the New York site of the Breast Cancer Family Registry. Carcinogenesis. 2012;33(10):1946-52. doi:10.1093/carcin/bgs201.

32. Delgado-Cruzata L, Wu HC, Perrin M, Liao Y, Kappil MA, Ferris JS, et al. Global DNA methylation levels in white blood cell DNA from sisters discordant for breast cancer from the New York site of the Breast Cancer Family Registry. Epigenetics. 2012;7(8):868-74. doi:10.4161/epi.20830.

33. Kitkumthorn $\mathrm{N}$, Tuangsintanakul T, Rattanatanyong P, Tiwawech D, Mutirangura A. LINE-1 methylation in the peripheral blood mononuclear cells of cancer patients. Clin Chim Acta. 2012:413(9-10):869-74. doi:10.1016/j.cca.2012.01.024 
34. Hajikhan Mirzaei M, Noruzinia M, Karbassian H, Shafeghati Y, Keyhanee M, Bidmeshki-Pour A. Evaluation of methylation status in the 5'UTR promoter region of the DBC2 gene as a biomarker in sporadic breast cancer. Cell J. 2012;14(1):19-24.

35. Askari M, Sobti RC, Nikbakht M, Sharma SC. Aberrant promoter hypermethylation of p21 (WAF1/CIP1) gene and its impact on expression and role of polymorphism in the risk of breast cancer. Molecular and Cellular Biochemistry. 2013;382(1-2):19-26. doi:10.1007/s11010-013-1696-5.

36. Kuchiba A, Iwasaki M, Ono H, Kasuga Y, Yokoyama S, Onuma H, et al. Global methylation levels in peripheral blood leukocyte DNA by LUMA and breast cancer: a case-control study in Japanese women. Br J Cancer. 2014;110(11): 2765-71. doi:10.1038/bjc.2014.223.

37. Gupta S, Jaworska-Bieniek K, Narod SA, Lubinski J, Wojdacz TK, Jakubowska A. Methylation of the BRCA1 promoter in peripheral blood DNA is associated with triple-negative and medullary breast cancer. Breast Cancer Res Treat. 2014;148(3):615-22. doi:10.1007/s10549-014-3179-0.

38. Deroo LA, Bolick SC, Xu Z, Umbach DM, Shore D, Weinberg CR, et al. Global DNA methylation and one-carbon metabolism gene polymorphisms and the risk of breast cancer in the Sister Study. Carcinogenesis. 2014;35(2):3338. doi:10.1093/carcin/bgt342.

39. Cho YH, McCullough LE, Gammon MD, Wu HC, Zhang YJ, Wang Q, et al. Promoter hypermethylation in white blood cell DNA and breast cancer risk. J Cancer. 2015;6(9):819-24. doi:10.7150/jca.12174.

40. Yari K, Payandeh M, Rahimi Z. Association of the hypermethylation status of PTEN tumor suppressor gene with the risk of breast cancer among Kurdish population from Western Iran. Tumour Biol 2015. doi:10.1007/s13277-015-4731-1

41. Harrison K, Hoad G, Scott P, Simpson L, Horgan GW, Smyth E, et al. Breast cancer risk and imprinting methylation in blood. Clin Epigenetics. 2015;7(1): 92. doi:10.1186/s13148-015-0125-x.

42. Zmetakova I, Danihel L, Smolkova B, Mego M, Kajabova V, Krivulcik T, et al. Evaluation of protein expression and DNA methylation profiles detected by pyrosequencing in invasive breast cancer. Neoplasma. 2013;60(6):635-46. doi:10.4149/neo_2013_082.

43. Ng EK, Shin VY, Leung CP, Chan WW, Law FB, Siu MT, et al. Elevation of methylated DNA in KILLIN/PTEN in the plasma of patients with thyroid and/ or breast cancer. Onco Targets Ther. 2014;7:2085-92. doi:10.2147/ott.s53597.

44. Hoque MO, Feng Q, Toure P, Dem A, Critchlow CW, Hawes SE, et al. Detection of aberrant methylation of four genes in plasma DNA for the detection of breast cancer. J Clin Oncol. 2006;24(26):4262-9. doi:10.1200/jco. 2005.01.3516.

45. Papadopoulou E, Davilas E, Sotiriou V, Georgakopoulos E, Georgakopoulou S, Koliopanos A, et al. Cell-free DNA and RNA in plasma as a new molecular marker for prostate and breast cancer. Ann N Y Acad Sci. 2006;1075:235-43. doi:10.1196/annals.1368.032.

46. Yazici H, Terry MB, Cho YH, Senie RT, Liao Y, Andrulis I, et al. Aberrant methylation of RASSF1A in plasma DNA before breast cancer diagnosis in the Breast Cancer Family Registry. Cancer Epidemiol Biomarkers Prev. 2009; 18(10):2723-5. doi:10.1158/1055-9965.epi-08-1237.

47. Radpour R, Barekati Z, Kohler C, Lv Q, Burki N, Diesch C, et al. Hypermethylation of tumor suppressor genes involved in critical regulatory pathways for developing a blood-based test in breast cancer. PLoS One. 2011;6(1):e16080. doi:10.1371/journal.pone.0016080.

48. Ng EK, Leung CP, Shin $\mathrm{V}$, Wong $\mathrm{CL}$, Ma ES, Jin HC, et al. Quantitative analysis and diagnostic significance of methylated SLC19A3 DNA in the plasma of breast and gastric cancer patients. PLoS One. 2011;6(7):e22233. doi:10.1371/journal.pone.0022233.

49. Chimonidou M, Tzitzira A, Strati A, Sotiropoulou G, Sfikas C, Malamos N, et al. CST6 promoter methylation in circulating cell-free DNA of breast cancer patients. Clin Biochem. 2013;46(3):235-40. doi:10.1016/j.clinbiochem. 2012.09.015

50. Dulaimi E, Hillinck J, Caceres II, Al-Saleem T, Cairns P. Tumor suppressor gene promoter hypermethylation in serum of breast cancer patients. Clinical Cancer Research. 2004;10:6189-93.

51. Martinez-Galan J, Torres B, Del Moral R, Munoz-Gamez JA, Martin-Oliva D, Villalobos M, et al. Quantitative detection of methylated ESR1 and 14-3-3-sigma gene promoters in serum as candidate biomarkers for diagnosis of breast cancer and evaluation of treatment efficacy. Cancer Biol Ther. 2008;7(6):958-65.

52. Van der Auwera I, Elst HJ, Van Laere SJ, Maes H, Huget P, van Dam P, et al. The presence of circulating total DNA and methylated genes is associated with circulating tumour cells in blood from breast cancer patients. Br J Cancer. 2009;100(8):1277-86. doi:10.1038/sj.bjc.6605013.
53. Chen Z, Fan JQ, Li J, Li QS, Yan Z, Jia XK, et al. Promoter hypermethylation correlates with the Hsulf-1 silencing in human breast and gastric cancer. Int J Cancer. 2009;124(3):739-44. doi:10.1002/ijc.23960.

54. Zurita M, Lara PC, del Moral R, Torres B, Linares-Fernandez JL, Arrabal SR, et al. Hypermethylated 14-3-3-sigma and ESR1 gene promoters in serum as candidate biomarkers for the diagnosis and treatment efficacy of breast cancer metastasis. BMC Cancer. 2010;10:217. doi:10.1186/1471-2407-10-217.

55. Ahmed IA, Pusch CM, Hamed T, Rashad H, Idris A, El-Fadle AA, et al. Epigenetic alterations by methylation of RASSF1A and DAPK1 promoter sequences in mammary carcinoma detected in extracellular tumor DNA. Cancer Genet Cytogenet. 2010;199(2):96-100. doi:10.1016/j.cancergencyto. 2010.02.007.

56. Brooks JD, Cairns P, Shore RE, Klein CB, Wirgin I, Afanasyeva Y, et al. DNA methylation in pre-diagnostic serum samples of breast cancer cases: results of a nested case-control study. Cancer Epidemiol. 2010;34(6):717-23. doi:10. 1016/j.canep.2010.05.006.

57. Kim JH, Shin MH, Kweon SS, Park MH, Yoon JH, Lee JS, et al. Evaluation of promoter hypermethylation detection in serum as a diagnostic tool for breast carcinoma in Korean women. Gynecol Oncol. 2010;118(2):176-81. doi:10.1016/j.ygyno.2010.04.016.

58. Kloten V, Becker B, Winner K, Schrauder MG, Fasching PA, Anzeneder T, et al. Promoter hypermethylation of the tumor-suppressor genes ITIH5, DKK3, and RASSF1A as novel biomarkers for blood-based breast cancer screening. Breast Cancer Res. 2013;15(1):R4. doi:10.1186/bcr3375.

59. Swellam M, Abdelmaksoud MDE, Mahmoud MS, Ramadan A, Abdel-Moneem W, Hefny MM. Aberrant methylation of APC and RAR beta(2) genes in breast cancer patients. lubmb Life. 2015;67(1):61-8. doi:10.1002/iub.1346.

60. Liu L, Sun L, Li C, Li X, Zhang Y, Yu Y, et al. Quantitative detection of methylation of FHIT and BRCA1 promoters in the serum of ductal breast cancer patients. Biomed Mater Eng. 2015;26 Suppl 1:S2217-2222. doi:10. 3233/bme-151527

61. Madhavan D, Wallwiener M, Bents K, Zucknick M, Nees J, Schott S, et al. Plasma DNA integrity as a biomarker for primary and metastatic breast cancer and potential marker for early diagnosis. Breast Cancer Res Treat. 2014;146(1):163-74. doi:10.1007/s10549-014-2946-2.

62. Chiu RW, Chan LY, Lam NY, Tsui NB, Ng EK, Rainer TH, et al. Quantitative analysis of circulating mitochondrial DNA in plasma. Clin Chem. 2003;49(5):719-26.

63. Suzuki N, Kamataki A, Yamaki J, Homma Y. Characterization of circulating DNA in healthy human plasma. Clin Chim Acta. 2008;387(1-2):55-8. doi:10.1016/j.cca.2007.09.001.

64. van der Vaart M, Pretorius PJ. Characterization of circulating DNA in healthy human plasma. Clin Chim Acta. 2008;395(1-2):186. doi:10.1016/j.cca.2008.05.006

65. Vaart Mvd, Pretorius PJ. The origin of circulating free DNA. Clin Chem 2007; 53(12). doi:10.1373/clinchem.2007.09273410.1373/clinchem.2007.097071.

66. Brooks J, Cairns P, Zeleniuch-Jacquotte A. Promoter methylation and the detection of breast cancer. Cancer Causes Control. 2009;20(9):1539-50. doi:10.1007/s10552-009-9415-y.

67. Yang AS, Estecio MR, Doshi K, Kondo Y, Tajara EH, Issa JP. A simple method for estimating global DNA methylation using bisulfite PCR of repetitive DNA elements. Nucleic Acids Res. 2004;32(3):e38. doi:10.1093/nar/gnh032.

68. Lander ES, Linton LM, Birren B, Nusbaum C, Zody MC, Baldwin J, et al. Initial sequencing and analysis of the human genome. Nature. 2001;409(6822): 860-921. doi:10.1038/35057062.

69. Houseman EA, Accomando WP, Koestler DC, Christensen BC, Marsit CJ, Nelson $\mathrm{HH}$, et al. DNA methylation arrays as surrogate measures of cell mixture distribution. BMC Bioinformatics. 2012;13:86. doi:10.1186/1471-2105-13-86.

70. Koestler DC, Marsit CJ, Christensen BC, Accomando W, Langevin SM, Houseman EA, et al. Peripheral blood immune cell methylation profiles are associated with nonhematopoietic cancers. Cancer Epidemiol Biomarkers Prev. 2012;21(8):1293-302. doi:10.1158/1055-9965.epi-12-0361.

71. Sharma G, Mirza S, Prasad CP, Srivastava A, Gupta SD, Ralhan R. Promoter hypermethylation of p16INK4A, p14ARF, CyclinD2 and Slit2 in serum and tumor DNA from breast cancer patients. Life Sci. 2007:80(20):1873-81. doi:10.1016/j.lfs.2007.02.026.

72. Mirza S, Sharma G, Prasad CP, Parshad R, Srivastava A, Gupta SD, et al. Promoter hypermethylation of TMS1, BRCA1, ERalpha and PRB in serum and tumor DNA of invasive ductal breast carcinoma patients. Life Sci. 2007;81(4): 280-7. doi:10.1016/j.lfs.2007.05.012.

73. Shukla S, Mirza S, Sharma G, Parshad R, Gupta SD, Ralhan R. Detection of RASSF1A and RARbeta hypermethylation in serum DNA from breast cancer patients. Epigenetics. 2006;1(2):88-93. 
74. Hu XC, Wong IH, Chow LW. Tumor-derived aberrant methylation in plasma of invasive ductal breast cancer patients: clinical implications. Oncol Rep. 2003;10(6):1811-5.

75. Anker $P$, Stroun M. Circulating DNA in plasma or serum. Medicina (B Aires). 2000;60(5 Pt 2):699-702.

76. Lo YM, Zhang J, Leung TN, Lau TK, Chang AM, Hjelm NM. Rapid clearance of fetal DNA from maternal plasma. Am J Hum Genet. 1999;64(1):218-24. doi:10.1086/302205.

77. McPherson K, Steel CM, Dixon JM. Breast cancer-epidemiology, risk factors, and genetics. BMJ. 2000;321(7261):624-28

Submit your next manuscript to BioMed Central and we will help you at every step:

- We accept pre-submission inquiries

- Our selector tool helps you to find the most relevant journal

- We provide round the clock customer support

- Convenient online submission

- Thorough peer review

- Inclusion in PubMed and all major indexing services

- Maximum visibility for your research

Submit your manuscript at www.biomedcentral.com/submit
Biomed Central 